\title{
Microwave-Assisted Reaction of 2,3-Dichloronaphthoquinone with Aminopyridines
}

\author{
Ricardo A. Tapia, ${ }^{a} *$ Lorena Cantuarias, $^{a}$ Mauricio Cuéllar ${ }^{b}$ and Joan Villena ${ }^{b}$ \\ ${ }^{a}$ Facultad de Química, Pontificia Universidad Católica de Chile, Casilla 6094411, Santiago-22, Chile \\ ${ }^{b}$ Facultad de Farmacia, Universidad de Valparaíso, Casilla 5001, Valparaíso, Chile
}

\begin{abstract}
Piridilaminonaftoquinonas foram preparadas a partir da reação de 2,3-dicloro-1,4-naftoquinona e aminopiridinas empregando irradiação de microondas. O uso de microondas diminuiu os tempos de reação e forneceu os melhores rendimentos em todos os casos. As substâncias preparadas foram avaliadas em células de câncer de mama (MCF-7).
\end{abstract}

The synthesis of pyridylaminonaphthoquinones by microwave-assisted reaction of 2,3-dichloro1,4-naphthoquinone with aminopyridines is described. The use of microwave irradiation diminished the reaction times and improved the yields substantially in all these reactions. The compounds were tested for their cytotoxic activities against MCF-7 breast cancer cell line.

Keywords: 2,3-dichloronaphthoquinone, microwave irradiation, aminopyridines, cytotoxic activity

\section{Introduction}

The aminonaphthoquinone scaffold is part of the structure of numerous natural and synthetic products associated with cytotoxic, antibacterial, antimalarial, and antifungal activities. ${ }^{1}$ Furthermore, many heterocyclic aminoquinones have been reported to show antitumor activity. $^{2}$

Aclassical route to obtain 2-amino-1,4-naphthoquinones is by reaction of 1,4-naphthoquinones with amines followed by air oxidation or by nucleophilic addition-elimination on 2-halo-1,4-naphthoquinones. ${ }^{3,4}$ However, the generality of the methods is limited and most of them require long reaction times. In our continuous effort towards the synthesis of heterocyclic quinones with useful biological activities, ${ }^{5}$ we were interested in the preparation of 2-pyridylamino3-chloro-1,4-naphthoquinones because their potential as antitumor agents was unexplored. Calandra and Adams, ${ }^{6}$ and Truit and co-workers. ${ }^{7}$ have reported that reaction of 2,3-dichloro-1,4-naphthoquinone (1) with 2-aminopyridine (2) under reflux of ethanol gives 2-(2-pyridylamino)-3-chloro1,4-naphthoquinone (3), which affords 1,4-naphthoquinone derivative $\mathbf{4}$ upon treatment with acetic acid. However, Mosby and Boyle found that the reaction of $\mathbf{1}$ and $\mathbf{2}$ under reflux of ethanol in the presence of sodium bicarbonate

*e-mail: rtapia@puc.cl leads to 1,2-naphthoquinone derivative 5 (46\%) and not to 2-pyridylamino-1,4-naphthoquinone 3 neither $p$-quinone $\mathbf{4}$ (Scheme 1). ${ }^{8}$

Considering the importance of the pyridylamino1,4-naphthoquinone moiety as pharmacophoric scaffold, we became interested in the application of microwave irradiation to study the reaction of 2,3-dichloro-1,4naphthoquinone (1) with different aminopyridines. It is noteworthy that microwave techniques have been demonstrated as a valuable tool in accelerating the rate and yield of organic reactions in general. ${ }^{9}$

\section{Results and Discussion}

We first performed the reaction of dichloronaphthoquinone 1 with 2-aminopyridine (2) employing conventional heating. Thus, treatment of quinone $\mathbf{1}$ with one equivalent of $\mathbf{2}$ in refluxing ethanol for 15 hours gave $o$-quinone $\mathbf{5}$ in $45 \%$ yield. The melting point and ${ }^{1}$ HNMR spectra of compound $\mathbf{5}$ were in agreement with literature values, ${ }^{10}$ and thus Mosby and Boyle results were confirmed. ${ }^{8}$ The microwave-assisted condensation reaction of $\mathbf{1}$ and $\mathbf{2}$ in ethanol, afforded $o$-quinone $\mathbf{5}$ in 57\% yield on irradiation in a $10 \mathrm{~mL}$ microwave vial at $90^{\circ} \mathrm{C}$ for 60 minutes (Table 1, entry 1). Therefore, a dramatic reduction of reaction time as well as a yield increase was obtained using microwave irradiation. 


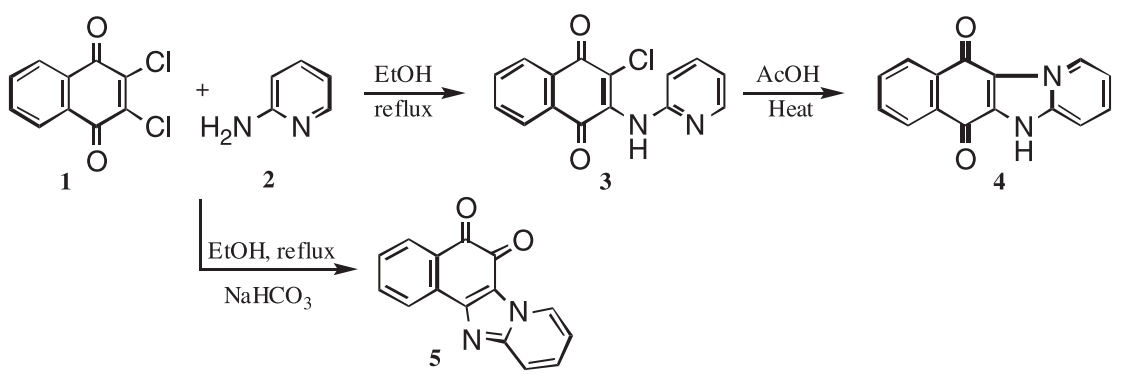

Scheme 1. Previous thermal studies on the reaction of $\mathbf{1}$ with $\mathbf{2}$.

Based on these findings, the reaction between dichloronaphthoquinone $\mathbf{1}$ and 3- and 4-aminopyridine $(6,7)$ was attempted. Using conventional heating, pyridylaminonaphthoquinone $\mathbf{8}$ was obtained in $40 \%$ yield upon treatment of quinone $\mathbf{1}$ with one equivalent of 3 -aminopyridine (6) in refluxing ethanol for 15 hours. The microwave accelerated condensation reaction of $\mathbf{1}$ and $\mathbf{6}$, as above in a $10 \mathrm{~mL}$ microwave vial at $90^{\circ} \mathrm{C}$ for 60 minutes, gave substituted naphthoquinone $\mathbf{8}$ in $70 \%$ yield (Table 1 , entry 2). For the reaction between dichloronaphthoquinone $\mathbf{1}$ and 4-aminopyridine (7), pyridylaminonaphthoquinone 9 was obtained in $40 \%$ yield after 15 hours in refluxing ethanol, while the microwave-assisted reaction afforded 9 in better yield (57\%) in 15 minutes (Table 1, entry 3).

The synthesis of pyridinylaminonaphthoquinone 11, as a model system, was studied as well. Amination reaction of 2-bromo-1,4-naphthoquinone (10) with 2-aminopyridine (2) under refluxing ethanol was unsuccessful, and starting materials were recovered. After this result, we decided to study this reaction using a palladium catalyst. ${ }^{11}$ It was found that $\mathrm{Pd}_{2}(\mathrm{dba})_{3}$ catalyst with $\mathrm{rac}$-BINAP as ligand and $\mathrm{Cs}_{2} \mathrm{CO}_{3}$ as base is a better choice for the coupling reaction between bromonaphthoquinone $\mathbf{1 0}$ and 2-aminopyridine (2). This coupling reaction was performed at $150{ }^{\circ} \mathrm{C}$ in toluene for 12 hours, to give $35 \%$ yield of compound $\mathbf{1 1}$, but under microwave irradiation the reaction time was 15 minutes and the yield was improved to $61 \%$ (Table 1, entry 4 ).

In the present study the in vitro cytotoxicity of the synthesized naphthoquinone derivatives against MCF-7 breast cancer cell line was evaluated using the Sulforhodamine B (Sigma) assay described by Skehan et al. ${ }^{12}$ The $\mathrm{IC}_{50}$ values for compounds $\mathbf{5}, \mathbf{8}, \mathbf{9}, \mathbf{1 1}$, and daunorubicin as the reference drug, are shown in Table 2. On the basis of these $\mathrm{IC}_{50}$ values, compound $\mathbf{5}$ was the most active although less potent than daunorubicin. The results are consistent with the concept that a planar conformation for a tricyclic structural pattern is a requirement for antitumor activity. ${ }^{13}$

Table 1. Conventional heating versus microwave irradiation on amination reaction of 1,4-naphthoquinones 1 and 10

\begin{tabular}{|c|c|c|c|c|c|c|c|c|}
\hline \multirow{2}{*}{ Entry } & \multirow{2}{*}{ Reactants } & \multirow{2}{*}{ Product } & \multicolumn{3}{|c|}{ Conventional heating } & \multicolumn{3}{|c|}{ Microwave irradiation } \\
\hline & & & $\mathrm{T} /\left({ }^{\circ} \mathrm{C}\right)$ & Yield/(\%) & time/h & $\mathrm{T} /\left({ }^{\circ} \mathrm{C}\right)$ & Yield/(\%) & time/min \\
\hline 1 & & & 78 & 45 & 15 & 90 & 57 & 60 \\
\hline 2 & 6 & 8 & 78 & 40 & 15 & 90 & 70 & 60 \\
\hline 3 & & & 78 & 45 & 15 & 90 & 57 & 15 \\
\hline 4 & 2 & 11 & 150 & 35 & 12 & 120 & 61 & 15 \\
\hline
\end{tabular}


Table 2. $\mathrm{IC}_{50}$ cytotoxicity values $\left(\mu \mathrm{mol} \mathrm{L} \mathrm{L}^{-1}\right)$ of naphthoquinone derivatives against MCF-7 tumor cell line $\mathrm{M}^{12}$

\begin{tabular}{cc}
\hline Compound & $\mathrm{IC}_{50}{ }^{\mathrm{b}}$ \\
\hline $\mathbf{5}$ & 6.87 \\
$\mathbf{8}$ & $>100^{\mathrm{c}}$ \\
$\mathbf{9}$ & 10.37 \\
$\mathbf{1 1}$ & 85.70 \\
$\mathbf{1}$ & 30.74 \\
Daunorubicin & 0.16 \\
\hline
\end{tabular}

In conclusion, we have shown that use of microwave irradiation diminished the reaction times and improved the yields substantially in all these reactions (Table 1). The pyridoaminonaphthoquinone derivatives prepared in this study can be a good starting point for further chemical modification in the search for novel anticancer drugs.

\section{Experimental}

Reactions were carried out with a single mode cavity Discover Microwave apparatus. Microwave experiments were performed in a $10 \mathrm{~mL}$ sealed tube. Melting points were determined with a Meltemp apparatus and are uncorrected. IR spectra were obtained on a Bruker Model Vector 22 spectrophotometer. ${ }^{1} \mathrm{H}$ NMR spectra were recorded on a Bruker ACP-200 and AM-400 instruments. Chemical shifts are expressed in parts per million downfield to tetramethylsilane (TMS, $\delta$ scale) and coupling constants $(J)$ are reported in hertz. ${ }^{13} \mathrm{C}$ NMR spectra were recorded in $\mathrm{CDCl}_{3}$ at 50 and $100 \mathrm{MHz}$. Column chromatography was performed on silica gel Merck 60 (70-230 mesh). Elemental analyses were performed on a Fison EA 1108 CHNS-O analyzer. Accurate MS measurements were determined using a Thermo Finnigan MAT 95XP spectrometer at the Facultad Ciencias Químicas y Farmacéuticas, Universidad de Chile.

\section{General procedure for the reaction of 1 with aminopyridines}

\section{Conventional heating}

A solution of dichloronaphthoquinone 1 (2.0 g, $8.8 \mathrm{mmol})$ and the appropriate aminopyridine $(0.94 \mathrm{~g}$, $10 \mathrm{mmol})$ in ethanol $(5 \mathrm{~mL})$ was refluxed under nitrogen for $15 \mathrm{~h}$. The solution was concentrated under reduced pressure and the residue partitioned between water $(20 \mathrm{~mL})$ and ethyl acetate $(20 \mathrm{~mL})$. The aqueous phase was extracted with ethyl acetate $(2 \times 20 \mathrm{~mL})$ and the combined organic phases dried over $\mathrm{MgSO}_{4}$ and the solvent evaporated. The residue was purified by column chromatography $\left(\mathrm{AcOEt} / \mathrm{CHCl}_{3} ; 2: 8\right)$.

\section{Microwave irradiation conditions}

A mixture of dichloronaphthoquinone 1 (1.2 g, $5.3 \mathrm{mmol})$, the appropriate aminopyridine $(0.50 \mathrm{~g}$, $5.3 \mathrm{mmol})$ and ethanol $(3 \mathrm{~mL})$ in a $10 \mathrm{~mL}$ microwave vial was irradiated at $90^{\circ} \mathrm{C}$ for $60 \mathrm{~min}$. The solution was concentrated under reduced pressure and the residue partitioned between water $(20 \mathrm{~mL})$ and ethyl acetate (20 mL). The aqueous phase was extracted with ethyl acetate $(2 \times 20 \mathrm{~mL})$ and the combined organic phases dried over $\mathrm{MgSO}_{4}$ and the solvent evaporated. The residue was purified by column chromatography (AcOEt/ $\left.\mathrm{CHCl}_{3} ; 2: 8\right)$.

\section{4a,11-Diazabenzo[3,2-a]fluorene-5,6-dione (5)}

Yellow crystals, mp 302-303 ${ }^{\circ} \mathrm{C}$ (lit. ${ }^{8} 301-302{ }^{\circ} \mathrm{C}$ ).

\section{2-(3-Aminopyridyl)-3-chloro-1,4-naphthoquinone (8)}

Orange crystals, mp $250-251^{\circ} \mathrm{C}$; IR $(\mathrm{KBr}) \mathrm{v}_{\max } / \mathrm{cm}^{-1}$ : $1686(\mathrm{C}=\mathrm{O}) ;{ }^{1} \mathrm{H} \mathrm{NMR}\left(\mathrm{F}_{3} \mathrm{CCOOH}\right): 8.00-8.10(\mathrm{~m}, 2 \mathrm{H}$, H-6 and H-7), 8.55-8.80 (m, 4H, H-4', H-5, H-5', and H-8), 9.46 (d, 1H, J 7.3 Hz, H-3'), 10.04 (s, 1H, H-2'), $14.0(\mathrm{~s}, 1 \mathrm{H}, \mathrm{NH}) .{ }^{13} \mathrm{C} \mathrm{NMR}\left(\mathrm{F}_{3} \mathrm{CCOOH}\right): 112.9(\mathrm{CH})$, $113.1(\mathrm{CH}), 130.3(\mathrm{C}), 131.1(\mathrm{CH}), 131.6(\mathrm{CH}), 132.7$ $(\mathrm{CH}), 134.0(\mathrm{C}), 138.9(\mathrm{C}), 139.2(\mathrm{CH}), 142.6(\mathrm{C}), 147.2$ (CH), $159.2(\mathrm{C}), 163.4(\mathrm{CH}), 184.2$ (C), $184.8(\mathrm{C})$. HR-MS $m / z$ : calc. for $\mathrm{C}_{15} \mathrm{H}_{9} \mathrm{ClN}_{2} \mathrm{O}_{2} 284.0352$, found: 284.0353 .

\section{2-(4-Aminopyridyl)-3-chloro-1,4-naphthoquinone (9)}

Orange crystals, mp $248-250{ }^{\circ} \mathrm{C}$; IR $(\mathrm{KBr}) v_{\max } / \mathrm{cm}^{-1}$ : $1687(\mathrm{C}=\mathrm{O}) ;{ }^{1} \mathrm{H}$ NMR $\left(\mathrm{F}_{3} \mathrm{CCOOH}\right)$ : 7.55-7.75 (m, $3 \mathrm{H}, \mathrm{H}-6, \mathrm{H}-7$ and H-2'), 7.81 (dd, $1 \mathrm{H}, J 7.4$ and 1.0 Hz, H-6'), 7.85-7.95 (m, 3H, H-5', H-5 and H-8), 8.00 (dd, $1 \mathrm{H}, J 7.7$ and $\left.1.0 \mathrm{~Hz}, \mathrm{H}-3^{\prime}\right), 12.3$ (s, 1H, NH). ${ }^{13} \mathrm{C}$ NMR ( $\left.\mathrm{F}_{3} \mathrm{CCOOH}\right): 101.1(\mathrm{C}), 112.0(\mathrm{CH}), 132.5(\mathrm{CH})$, $133.6(\mathrm{CH}), 131.6(\mathrm{CH}), 132.7(\mathrm{CH}), 134.0(\mathrm{C}), 138.9$ (C), $139.2(\mathrm{CH}), 142.6(\mathrm{C}), 147.2(\mathrm{CH}), 159.2(\mathrm{C})$, $163.4(\mathrm{CH}), 184.2(\mathrm{C}), 184.8(\mathrm{C})$. HR-MS m/z: calc. for $\mathrm{C}_{15} \mathrm{H}_{9} \mathrm{ClN}_{2} \mathrm{O}_{2} 284.0352$, found: 284.0349 .

Reaction of 2-bromo-1,4-naphthoquinone (10) with 2-aminopyridine (2)

\section{Conventional heating}

A mixture of bromonaphthoquinone 10 (237 mg, $1.0 \mathrm{mmol})$, toluene $(2.0 \mathrm{~mL}), \mathrm{Pd}_{2}(\mathrm{dba})_{3}(46 \mathrm{mg}$, $0.05 \mathrm{mmol}$ ), rac-BINAP (47 mg, $0.075 \mathrm{mmol}$ ), $\mathrm{Cs}_{2} \mathrm{CO}_{3}$ (652 $\mathrm{mg}, 2.0 \mathrm{mmol}$ ) and aminopyridine 2 (94 $\mathrm{mg}$, $1 \mathrm{mmol}$ ) was heated in an autoclave at $150{ }^{\circ} \mathrm{C}$ for $12 \mathrm{~h}$. The solvent was evaporated at reduced pressure and the residue purified by column chromatography $\left(\mathrm{CHCl}_{3}\right)$. 


\section{Microwave irradiation conditions}

A mixture of bromonaphthoquinone $\mathbf{1 0}(237 \mathrm{mg}$, $1.0 \mathrm{mmol})$, toluene $(2.0 \mathrm{~mL}), \mathrm{Pd}_{2}(\mathrm{dba})_{3}(46 \mathrm{mg}, 0.05 \mathrm{mmol})$, rac-BINAP (47 mg, $0.075 \mathrm{mmol}), \mathrm{Cs}_{2} \mathrm{CO}_{3}(652 \mathrm{mg}$, $2.0 \mathrm{mmol}$ ) and aminopyridine $2(94 \mathrm{mg}, 1 \mathrm{mmol})$ ) in a $10 \mathrm{~mL}$ microwave vial was irradiated at $120^{\circ} \mathrm{C}$ for $15 \mathrm{~min}$. The solvent was evaporated at reduced pressure and the residue purified by column chromatography $\left(\mathrm{CHCl}_{3}\right)$.

\section{2-(2-Aminopyridyl)-1,4-naphthoquinone (11)}

Red crystals, mp 209-210 ${ }^{\circ} \mathrm{C}$; IR (KBr) $v_{\max } / \mathrm{cm}^{-1}: 1664$ $(\mathrm{C}=\mathrm{O}) ;{ }^{1} \mathrm{H} \mathrm{NMR}\left(\mathrm{CDCl}_{3}\right)$ : 6.95-7.05 (m, 2H, H-6 and H-7), 7.60-7.75 (m, 2H, H-5 and H-8), 7.81 (dd, 1H, J 7.4 and 1.6 Hz, H-6'), 8.00 (s, 1H, H-3), 8.05 (s, 1H, NH,), 8.108.15 (m, 2H, H-4' and H-5'), 8.40 (dd, 1H, J 7.3 and 2.0 $\left.\mathrm{Hz}, \mathrm{H}-3{ }^{\prime}\right) .{ }^{13} \mathrm{C} \mathrm{NMR}\left(\mathrm{CDCl}_{3}\right)$ : $112.9(\mathrm{CH}), 115.2(\mathrm{CH})$, $117.8(\mathrm{CH}), 124.0(\mathrm{CH}), 127.9(\mathrm{CH}), 129.1(\mathrm{C}), 129.6$ $(\mathrm{CH}), 129.7(\mathrm{C}), 130.0(\mathrm{CH}), 132.4(\mathrm{CH}), 134.7(\mathrm{C}), 137.7$ (CH), 148.9 (C), $183.4(\mathrm{C}), 183.6(\mathrm{C})$. HR-MS m/z: calc for $\mathrm{C}_{15} \mathrm{H}_{8} \mathrm{~N}_{2} \mathrm{O}_{2} 248.0585$, found: 248.0576 .

\section{Acknowledgments}

We are grateful to FONDECYT (Research Grant 1060592) and CONICYT (Fellowship to L. C. and Research Grant AT24080019) for financial support.

\section{References}

1. Sarma, M. D.; Ghosh, R.; Patra, A.; Hazra, B.; Eur. J. Med. Chem. 2008, 43, 1878; Kim, J. S.; Rhee, H-K.; Park, H. J.; Lee, I-K.; Lee, S. K.; Suh, M-E.; Lee, H. J.; Ryu, C-K.; Choo, H-Y. P.; Bioorg. Med. Chem. 2007, 15, 451; Bernardo, P. H.; Chai, C. L. L.; Le Guen, M.; Smith, G. D.; Waring, P.; Bioorg. Med. Chem. Lett. 2007, 17, 82.

2. Garuti, L.; Roberti, M.; Pizzirani, D.; Mini-Rev. Med. Chem. 2007, 7, 481; Asche, C.; Mini-Rev. Med. Chem. 2005, 5, 449; Bernardo, P. H.; Chai, C. L. L.; Heath, G. A.; Mahon, P. J.; Smith, G. D.; Waring, P.; Wilkes, B. A.; J. Med. Chem. 2004, 47, 4958.
3. Kutyrev, A. A.; Tetrahedron 1991, 47, 8043.

4. Aguilar-Martínez, M.; Cuevas, G.; Jiménez-Estrada, M.; González, I.; Lutina-Hennsen, B.; Macías-Ruvalcada, N.; J. Org. Chem. 1999, 64, 3684.

5. Tapia, R. A.; López, C.; Morello, A.; Maya, J. D.; Valderrama, J. A.; Synthesis 2005, 903; Tapia, R. A.; Salas, C.; Morello,A.; Maya, J. D.; Toro-Labbé, A.; Bioorg. Med. Chem. 2004, 12, 2451.

6. Calandra, J. C.; Adams, E. C.; J. Am. Chem. Soc. 1950, 72, 4804.

7. Truitt, P.; Cooper, J. E.; Wood, F. M.; J. Am. Chem. Soc. 1957, 79, 5708 .

8. Mosby, W. I.; Boyle, R. J.; J. Org. Chem. 1959, 24, 374.

9. Polshettiwar, V.; Varma, R. S.; Acc. Chem. Res. 2008, 41, 629; Bueno, M. A.; Silva, L. R. S. P.; Corrêa, A. G.; J. Braz. Chem. Soc. 2008, 19, 1264; da Silva, A. R.; da Silva, A. M.; Ferreira, A. B. B.; Bernardes, B. de O.; da Costa, R. L.; J. Braz. Chem. Soc. 2008, 19, 1230; Braibante, M. E. F.; Braibante, H. T. S.; Uliana, M. P.; Costa, C. C.; Spenazzatto, M.; J. Braz. Chem. Soc. 2008, 19,909; Moghaddam, F. M.; Bardajee, G. R.; Ismaili, H.; J. Braz. Chem. Soc. 2007, 18, 1024; Qu, G.; Zhang, Z.; Guo, H.; Geng, M.; Xia, R.; J. Braz. Chem. Soc. 2007, 18, 1061; Suna, E.; Mutule, I.; Top. Curr. Chem. 2006, 266, 49; De la Hoz, A.; Díaz-Ortiz, A.; Moreno, A.; Chem. Soc. Rev. 2005, 34, 164; Kappe, C. O.; Angew. Chem., Int. Ed. 2004, 43, 6250.

10. Laréginie, P.; Lokshin, V.; Samat, A.; Guglielmetti, R.; Pèpe, G.; J. Chem. Soc., Perkin Trans 2 1996, 107.

11. Wang, X-L.; Zheng, X-Z.; Reiner, J.; Synlett 2006, 942; Wang, X-L.; Zheng, X-F.; Wang, L.; Reiner, J.; Lin, W. L.; Chang, J. B.; Synthesis 2007, 989.

12. Skehan, P.; Storeng, R.; Scudiero, D.; Monks, A.; McMahon, J.; Vistica, D.; Warren, J. T.; Bokesch, H.; Kenney, S.; Boyd, M. R.; J. Natl. Cancer Inst. 2006, 82, 1107.

13. Cheng, C. C. In Progress in Medicinal Chemistry; Ellis, G. P.; West, G. B., eds.; Elsevier: Amsterdam, 1988, vol. 25, pp. 35-83.
Received: January 6, 2009

Web Release Date: April 3, 2009 